\title{
CLINICAL ASPECTS AND CASE MANAGEMENT IN A PATIENT WITH LONG QT SYNDROME, PROBABLY GENETIC
}

\author{
Violeta Ion ${ }^{1,2}$, Cristina Pascari ${ }^{2}$, Florina Cristescu ${ }^{2}$ \\ "Elias" Emergency University Hospital \\ ${ }^{2}$ Medical Center Promemoria \\ Correspondence address: Str. General David Praporgescu nr. 1-5, Bucharest \\ e-mail:violeta.tina.ion@gmail.com
}

\begin{abstract}
We present the evaluation of a 82 years old patient, diagnosed with long QT syndrome at 75 years (QTC $=550 \mathrm{~ms}$ ) and obstructive hypertrophic cardiomyopathy from 2011, complicated with ventricular fibrillation and torsade de pointes (QTC $=840 \mathrm{~ms}$ ). In this situation, it was decided to follow via electrocardiography (ECG) her first and second degree relatives (daughter -53 years old - QTC $=505$ ms, granddaughter -23 years old $-Q T C=448 m s$ ), and to inform them about the importance of performing the cardiac echography to exclude a possible obstructive hypertrophic cardiomyopathy, and of the genetic testing. After the implantation of the ICD (implantable cardiac defibrillator) and on treatment with beta-blockers, the patient did not repeat any arrhythmic events, but still had the same electrocardiographic aspect of long $Q T$ interval. Due to the fact that the patient had a lot of other diseases, the administration of treatment which can prolong the QT interval was avoided. Long QT syndrome represents a congenital or acquired pathology, which sometimes can be induced by some drugs, and requires a correct diagnosis in order to establish an individualized pharmaceutical or surgical treatment, and to prevent the risk of sudden death by cardiac arrhythmias.
\end{abstract}

Keywords: long QT syndrome, sudden death, cardiac arrhythmias, genetic disease.

\section{Rezumat}

Am evaluat o pacientă în vârstă de 82 de ani, diagnosticată cu sindrom QT lung la vârsta de 75 de ani (QTc=550ms) și cu cardiomiopatie hipertrofică obstructivă cunoscută din 2011, care s-a complicat cu stop cardiorespirator prin fibrilație ventriculară resuscitat și torsada vârfurilor (QT =840 ms). În acest context s-a decis urmărirea electrocardiografică (ECG) a rudelor de gradul I și II (fiica - 53 ani - QTC=505 ms, nepoata - 23ani-QTc =448ms) și informarea acestora cu privire la importanța efectuării ecografiei cardiace pentru excluderea cardiomiopatiei 


\section{INTERNAL}

\section{Clinical cases}

hipertrofice obstructive și a testării genetice. Pacienta, în urma implantării stimulatorului cardiac de tip ICD (implantable cardiac defibrillator) și sub tratament medicamentos cu betablocant nu a mai repetat evenimente aritmice, însă menține aspect ECG de QT lung. În contextul multiplelor comorbidități s-a evitat administrarea de substanțe medicamentoase care induc alungirea segmentului QT. Sindromul QT lung reprezintă o patologie a cărei etiologie poate fi congenitală sau dobândită, de cauză medicamentoasă sau nemedicamentoasă și impune un diagnostic corect pentru tratament chirurgical și medicamentos adecvat și pentru prevenirea riscului de moarte subită prin aritmii cardiace.

Cuvinte cheie: sindrom QT lung, moarte subită, aritmii cardiace, boală genetică.

\section{Introduction}

Long QT syndrome (LQTS) is a genetic or acquired disorder characterised by the prolongation of the QT interval on the ECG (QTc>480 ms in 12 leads) in lack of other cause of QT prolongation. Patients with prolonged QT on the electrocardiogram (ECG) are predisposed to developing cardiac ventricular arrhythmias which can lead to syncope, heart failure or sudden death. This syndrome is rarely diagnosed due to the fact that there are LQT gene carriers who have normal values of QTC on the ECG.

The prevalence of long QT syndrome is of 1:2000 - 1:3000 of live newborns, females $>$ males.

The etiology of this disorder can be genetic or acquired (through administration of medical agents which prolong the QT interval or nondrug-induced).
Genetic long QT syndrome is caused by mutations of genes which code the sodium, potassium and calcium ion channels. There have been 10 responsible genes identified. Mutations of genes

- LQT1 gene affects the potassium channels which remain open a longer period of time than normal and lead to the delay of ventricular repolarization. Beta-blockers have a very good efficiency in patients presenting this mutation.

- LQT2 gene - the affected potassium channels close faster and produce delayed ventricular repolarization. In pre- and postmenopausal women the mutation of this gene increases the risk of sudden death compared to women of fertile age.

- LQT3 mutation affects the sodium channels which lead to delayed 


\begin{tabular}{|c|c|c|c|}
\hline Type of LQTS & $\begin{array}{l}\text { Chromosomal } \\
\text { Locus }\end{array}$ & Mutated Gene & $\begin{array}{l}\text { Ion Current } \\
\text { Affected }\end{array}$ \\
\hline LQT1 & $11 p 15.5$ & $\begin{array}{c}\text { KVLQT1 or KCNQ1 (heterozy } \\
\text { gotes) }\end{array}$ & Potassium $\left(\mathrm{I}_{\mathrm{Ks}}\right)$ \\
\hline LQT2 & $7 q 35-36$ & HERG, KCNH2 & Potassium $\left(I_{\mathrm{Kr}}\right)$ \\
\hline LQT3 & $3 p 21-24$ & SCN5A & Sodium $\left(I_{\mathrm{Na}}\right)$ \\
\hline LQT4 & $4 q 25-27$ & $A N K 2, A N K B$ & $\begin{array}{l}\text { Sodium, potassium } \\
\text { and calcium }\end{array}$ \\
\hline LQT5 & $21 q 22.1-22.2$ & KCNE1 (heterozygotes) & Potassium (I $\left.\mathrm{Ks}_{\mathrm{S}}\right)$ \\
\hline LQT6 & $21 q 22.1-22.2$ & MiRP1, KNCE2 & Potassium $\left(I_{\mathrm{Kr}}\right)$ \\
\hline $\begin{array}{l}\text { LQT7 (Anderson } \\
\text { syndrome) }\end{array}$ & $17 q 23.1-q 24.2$ & KCNJ2 & Potassium $\left(I_{K 1}\right)$ \\
\hline $\begin{array}{l}\text { LQT8 (Timothy } \\
\text { syndrome) }\end{array}$ & $12 q 13.3$ & CACNAIC & Calcium (I ${ }_{\text {Ca-Lalpha }}$ ) \\
\hline LQT9 & $3 p 25.3$ & CAV3 & Sodium $\left(I_{\mathrm{Na}}\right)$ \\
\hline LQT10 & $11 q 23.3$ & $S C N 4 B$ & Sodium $\left(I_{\mathrm{Na}}\right)$ \\
\hline LQT11 & $7 q 21-q 22$ & $A K A P 9$ & Potassium $\left(\mathrm{I}_{\mathrm{Ks}}\right)$ \\
\hline LQT12 & & SNTAI & Sodium $\left(I_{\mathrm{Na}}\right)$ \\
\hline JLN1 & $11 \mathrm{p} 15.5$ & $\begin{array}{c}K V L Q T 1 \text { or } K C N Q 1 \text { (homozyg } \\
\text { otes) }\end{array}$ & Potassium (I $\left.\mathrm{K}_{\mathrm{Ks}}\right)$ \\
\hline JLN2 & $21 q 22.1-22.2$ & KCNE1 (homozygotes) & Potassium $\left(I_{\mathrm{Ks}}\right)$ \\
\hline
\end{tabular}

Table 1. Gene LQT(13)

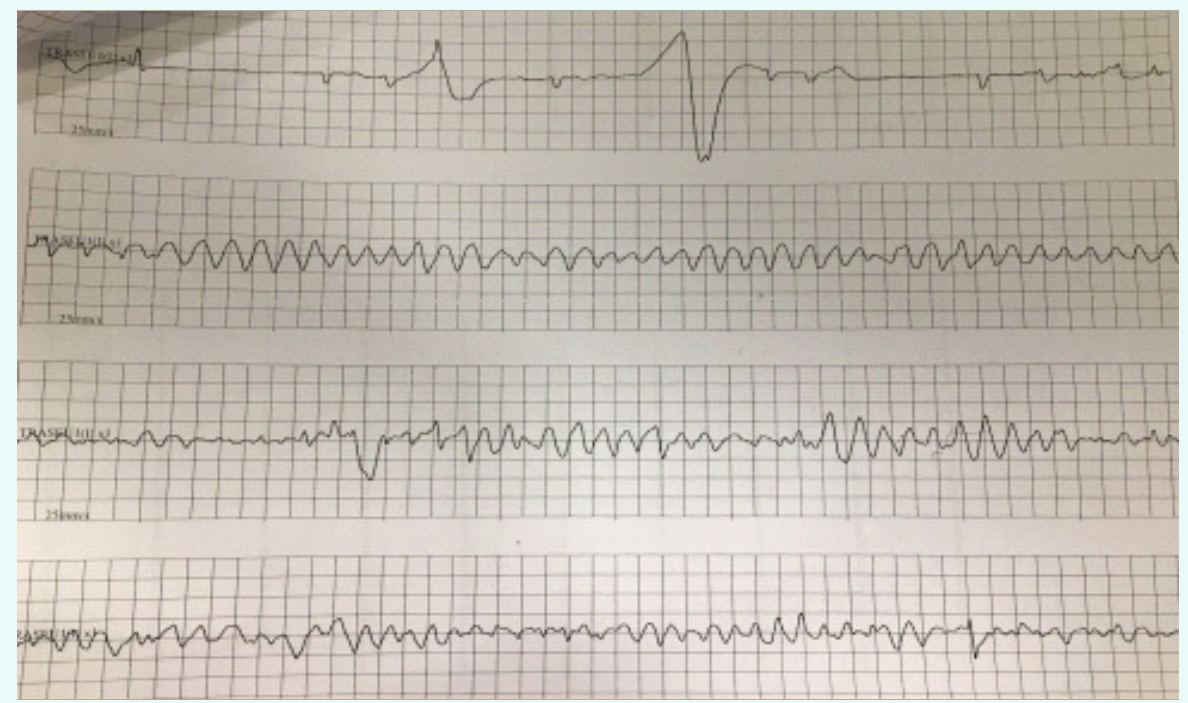

Figure 1. Torsade de pointes 
INTERNAL

\section{Clinical cases}

repolarization by increasing the intensity of the sodium flow in the plateau phase. Responsible for these kind of alterations seem to be fragments of proteins which can be found at the level of cellular membranes of myocytes and fibroblasts. There have been discovered approximately 50 mutations of this gene, among them being the Brugada Syndrome.

- LQT4 gene encodes ankyrin-B which is an adapting protein that binds to proteins at the level of various ion channels, especially calcium channels. The result will reside in an increase in the level of intracellular calcium, which will lead to ventricular arrhythmias.

- The LQT5,6,7,8,9,10 gene mutations affect most commonly the potassium ion channels. Andersen Syndrome (LQT7) is associated with musculoskeletal malformations and scoliosis. Timothy Syndrome (LQT8) is associated with cardiac malformations, cognitive and behaviour disorders, musculoskeletal and autoimmune diseases.

\section{Diagnosis}

The diagnosis of this syndrome is not very often clinical. However there are cases in which the patient presents severe bradycardia or severe congenital hypoacusis, in the latter case it may be Jervell and Large-Nielsen Syndrome. The paraclinical diagnosis requires:

- dosing of magnesium, potassium and sodium levels

- thyroid function testing (TSH, fT4, fT3, ATPO)

- ECG of the patient and relatives

- genetic testing of first degree relatives

\section{Treatment}

Currently there is no treatment which can address directly the cause of LQTS. The treatment which can lower the risk of sudden death is the administration of beta-blocker, performing right cervicothoracic stellectomy, ICD or pacemaker implantation.

Studies have shown that administration of beta-blockers decreases the risk of mortality by approximately $2 \%$.

- Nadolol - with inotropic negative effect, long-term effect

- Propranolol - negative inotropic and chronotropic effect, lowers the electric conduction through the sino-atrial node

- Metoprolol

- Atenolol

The patients diagnosed with LQTS must avoid certain situations (sport, intense physical effort, negative emotions, sleep deprivation) and certain medications which can precipitate 


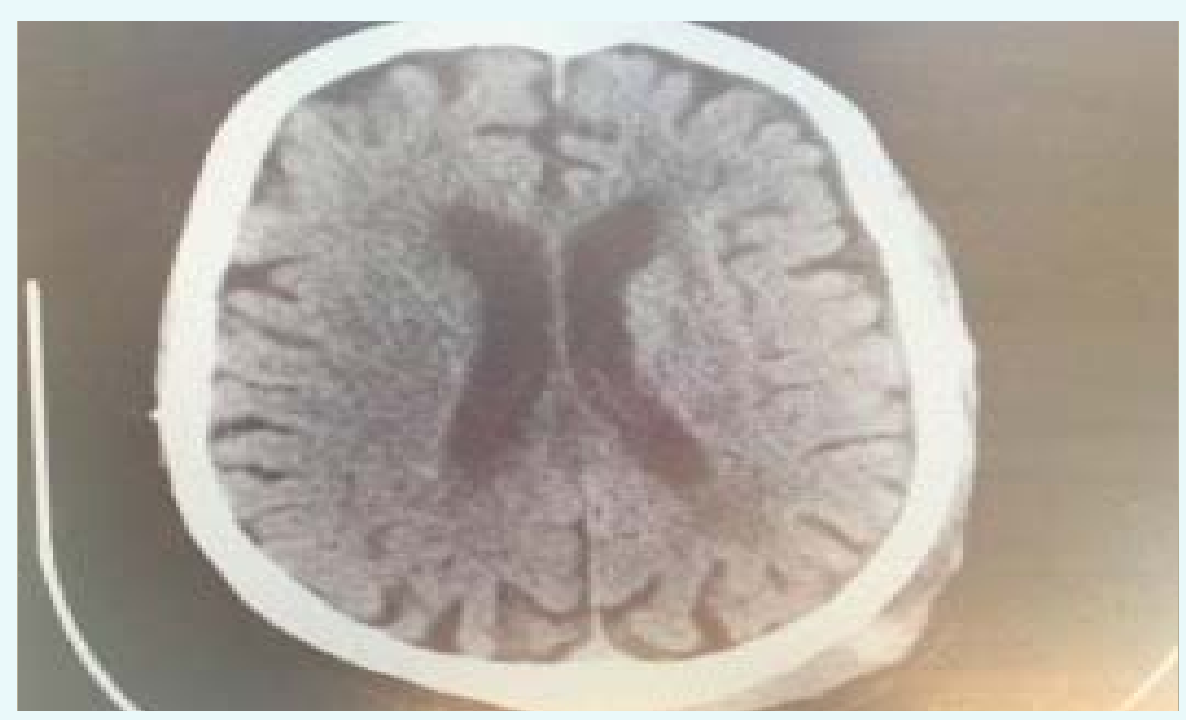

Figure 2. CT scan: Cerebral atrophy, leukoaraiosis

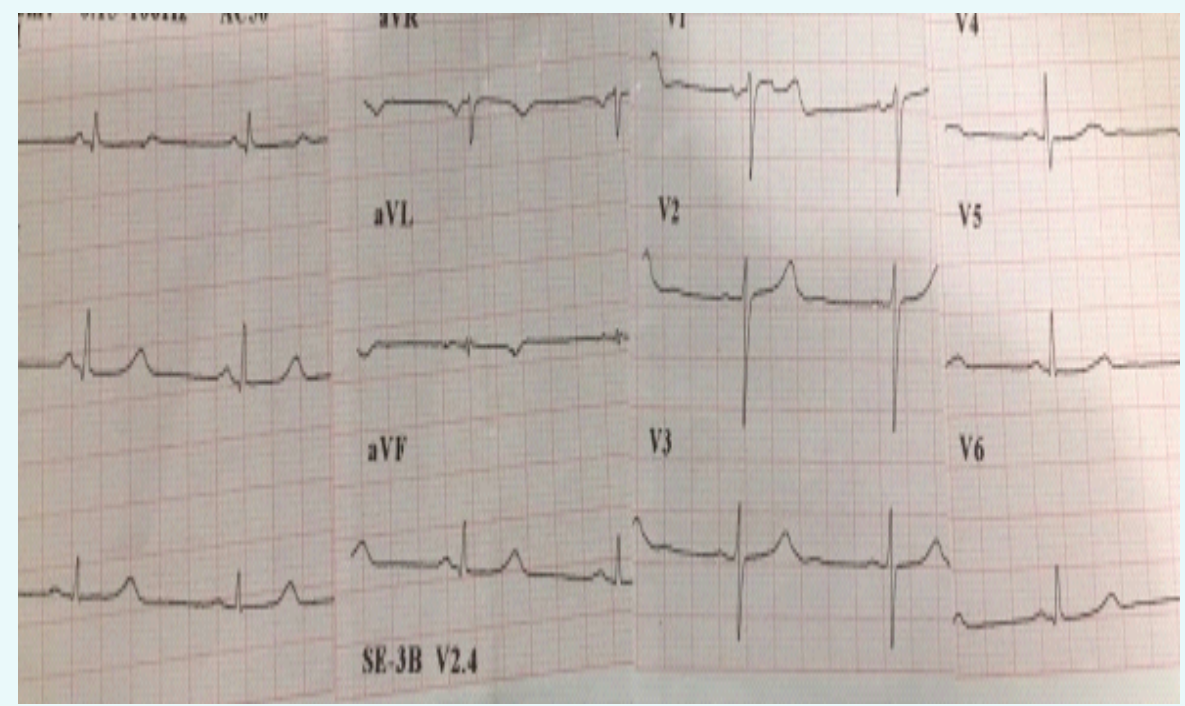

Figure 3. Patient's daughter ECG: $Q T C=505 \mathrm{~ms}$ 


\section{INTERNAL}

\section{Clinical cases}

the prolongation of the QT interval with the onset of cardiac events such as ventricular arrhythmias and sudden death.

Medications which can induce prolongation of QT interval:

- Anesthetics and bronchodilators

- Antihistamines

- Certain antibiotics (erythromycin, trimethoprim and sulfamethoxazole)

- Quinidine, procainamide, sotalol

- Antifungals (ketoconazole, fluconazole)

- Tricyclic antidepressants, antipsychotics

- Diuretics (indapamide), anti-emetics and anti-diarrheal drugs which can induce dyselectrolytemias.

(www.sads.org.uk/drugs-to-avoid) - the complete list of medications contraindicated for patients with LQTS

\section{Case presentation}

Female patient, aged 82 years old, nonsmoker, with drinking behaviour $(2000 \mathrm{~mL}$ beer/day) with a long known pathologic personal history:

- cholecystectomy in 1994

- Car accident with multiple trauma and fractures in 1998

- partial gastric resection and acute hemorrhagic pancreatitis operated in 2000 , successively

- primary arterial hypertension grade II, high additional risk (maximal value known of systolic arterial pressure $=200$ $\mathrm{mmHg}$ )

- mixed dyslipidemia

- hypertrophic obstructive cardiomyopathy (HOCM), Qtc on ECG with a duration of $550 \mathrm{~ms}-2011$

The patient was admitted in December 2015 with an episode of ventricular fibrillation with cardiac-respiratory arrest resuscitated at home, in the context of an atrio-ventricular block of high grade complicated with torsade de pointes, subsequently with the implantation of a DDD-type pacemaker. The transthoracic echocardiography that was performed revealed asymmetric HOCM with intraventricular obstruction, mitral regurgitation through a mixed mechanism, tricuspid regurgitation and overall systolic function preserved. On the ECG performed at admission, $\mathrm{QTc}=840 \mathrm{~ms}$.

At 3 days after the implantation of the DDDtype pacemaker, the patient presented signs of congestive heart failure, hardly responsive to treatment, accompanied by cardiogenic acute pulmonary oedema and episodes of unsustained ventricular tachycardia on the ECG Holter monitoring. In this context we decided to replace the DDD-type pacemaker with a bicameral ICD.

The patient was discharged with beta-blocker treatment (Metoprolol), diuretics, angiotensinconverting-enzyme inhibitor and platelet 
inhibitor. In October 2017, the patient underwent a cognitive and behaviour evaluation at the request of her daughter. She stated the fact that since approximately 2 years, the patient has had frequent confusion episodes with temporal and spatial disorientation, verbal aggressiveness, irascibility, inadequate vocabulary, repetitive behaviour, memory disorders for recent events.

The cognitive evaluation at that moment: Mini Mental State Examination (MMSE) $=26 / 30$, Activity of Daily Living $(A D L)=6 / 6$, Instrumental Activity of Daily Living (IADL) $=8 / 8$, Watch test $=9 / 10$, Yesavage (Geriatric Depression Scale) $=3 / 15$. Cerebral CT: shows a spontaneous hypodensity of the white matter which encloses the lateral ventricles with an extension slightly inhomogeneous in the centrum semiovale, left parietal area, cerebral atrophy and leukoaraiosis. Corroborating the anamnestic, biological and imagistic data together with the cognitive evaluation and taking into consideration the numerous cardiovascular comorbidities, it was decided to initiate the treatment of the neurocognitive disorder with N-Methyl-D-aspartate (NMDA) receptor antagonist, treatment of the conduct disorder with sodium valproate, treatment of depression with tianeptine, given the contraindication for administration of tricyclic antidepressants. The status of the patient had been stable until March 2019, when she was admitted to the emergency department for a syncopal episode accompanied by falling at home. The CT scan performed at that moment featured a left occipital epidural hematoma, cerebral and cerebellar atrophy, and as an addition to the 2017 examination, it is noted an area of hypodensity at the level of the right side of centrum semiovale.

Cervico-cerebral Doppler investigation showed bilateral carotid atherosclerosis, nonhemodynamically significant. Cardiac echocardiography showed hypertrophic obstructive cardiomyopathy (HOCM) with left ventricular outflow tract obstruction, with normal ejection fraction, mitral and tricuspid regurgitation, and possible pulmonary hypertension.

Holter ECG examination identified 667 isolated multiform premature ventricular contractions, 19 ventricular couplets with 5 episodes of nonsustained ventricular tachycardia.

Biologically a mild hyponatremia was noted (129 mmol/L). The cognitive evaluation MMSE $=19 / 30$ (cognitive decline compared to the evaluation prior to the episode for which she was admitted to the hospital), watch test $=7 / 10, \mathrm{ADL}=6 / 6, \mathrm{IADL}=3 / 8$. At the moment of discharge the following treatment was decided: NMDA antagonist, mood stabiliser, beta-blocker, angiotensin-converting-enzyme inhibitor, calcium channel blocker, statin, and antidepressant.

\section{Conclusions}

The patient associates a multitude of risk factors:

- female gender

- structural cardiac anomaly: hypertrophic obstructive cardiomyopathy (HOCM)

- alcohol intake which can lead to absorption disorders for $\mathrm{Ca}, \mathrm{Mg}, \mathrm{K}, \mathrm{Na}$

- treatment with loop diuretic

The progressive cognitive impairment has most probably occurred in the context of cerebral hypoxia, repetitive cerebrovascular accidents and alcohol intake.

Due to high suspicion of a genetic pathology, it was decided that all first degree relatives (daughter and granddaughter) undergo an EKG, which revealed:

- daughter 53 years: QTC $=505 \mathrm{msec}$, $\mathrm{RS}=54 \mathrm{bpm}$ rhythmic

- daughter 23 years: QTc $=448 \mathrm{msec}$ 


\section{INTERNAL}

\section{Clinical cases}

Both daughter and granddaughter have been advised and guided to perform genetic testing for the correct diagnosis of the genetic mutation and the early as possible initiation of a specific and personalised treatment in order to avoid the possible cardiac complications and sudden death.

- LQTS is usually diagnosed after the patient develops a major cardiac event (e.g. cardiorespiratory arrest)

- Patient management with LQTS resides in antiadrenergic therapeutic measures:

$\rightarrow$ beta-blocker, left cervicothoracic stellectomy

$\rightarrow$ cardioverter defibrillator implantation

$\rightarrow$ avoidance of medications and risk factors that induce prolonged QT

- Patient and family education on the importance of beta-blocker treatment and avoiding risk factors for cardiac events, cardiopulmonary resuscitation training and performing genetic testing.

\section{References:}

1. Ackerman MJ, Priori SG, Dubin AM, et al. Beta-blocker therapy for long QT syndrome and catecholaminergic polymorphic ventricular tachycardia: Are all beta-blockers equivalent?. Heart Rhythm. 2017Jan. 14(1):e41-e44. [Medline]. 2. Heemskerk CPM, Pereboom M, van Stralen $K$, et al. Risk factors for QTC interval prolongation. Eur J Clin Pharmacol. 2018 Feb. 74(2):183-91. [Medline].

3. El-Sherif N, Turitto G, Boutjdir M. Congenital long QT syndrome and torsade de pointes. Ann Noninvasive Electrocardiol. 2017 Nov. 22(6):[Medline].

4. Wei H, Wu J, Liu Z. Studying KCNQ1 mutation and drug response in type 1 long QT syndrome using patient-specific induced pluripotent stem cell-derived cardiomyocytes. Methods Mol Biol. 2018. 1684:7-28. [Medline].

5. Duncan G, Firth $K$, George $V$, et al. Drug-mediated shortening of action potentials in LQTS2 human induced pluripotent stem cell-derived cardiomyocytes. Stem Cells Dev. 2017 Dec 1. 26(23):1695-705. [Medline].

6. Gong $Q$, Zhou Z. Nonsense-mediated mRNA decay of hERG mutations in long QT syndrome. Methods Mol Biol. 2018. 1684:37-49. [Medline].

7. Fukumoto D, Ding WG, Wada $Y$, et al. Novel intracellular transport-refractory mutations in KCNH2 identified in patients with symptomatic long QT syndrome. J Cardiol. 2018 Apr. 71(4):401-8. [Medline].

8. Perez-Riera AR, Barbosa-Barros R, Daminello Raimundo R, da Costa de Rezende Barbosa MP, Esposito Sorpreso IC, de Abreu LC. The congenital long QT syndrome Type 3: An update. Indian Pacing Electrophysiol J. 2018 Jan - Feb. 18(1):25-35. [Medline]. [Full Text].

9. Vatta M, Ackerman MJ, Ye B, et al. Mutant caveolin-3 induces persistent late sodium current and is associated with long-QT syndrome. Circulation. 2006 Nov 14. 114(20):2104-12. [Medline].

10. Napolitano C, Bloise R, Priori SG. Long QT syndrome and short QT syndrome: how to make correct diagnosis and what about eligibility for sports activity. J Cardiovasc Med (Hagerstown). 2006 Apr. 7(4):250-6. [Medline].

11. Roden DM. Long QT syndrome: reduced repolarization reserve and the genetic link. J Intern Med. 2006 Jan. 259(1):59-69. [Medline].

12. Schwartz PJ. The congenital long QT syndromes from genotype to phenotype: clinical implications. J Intern Med. 2006 Jan. 259(1):39-47. [Medline]

13. https://emedicine.medscape.com/article/157826overview\#a4 